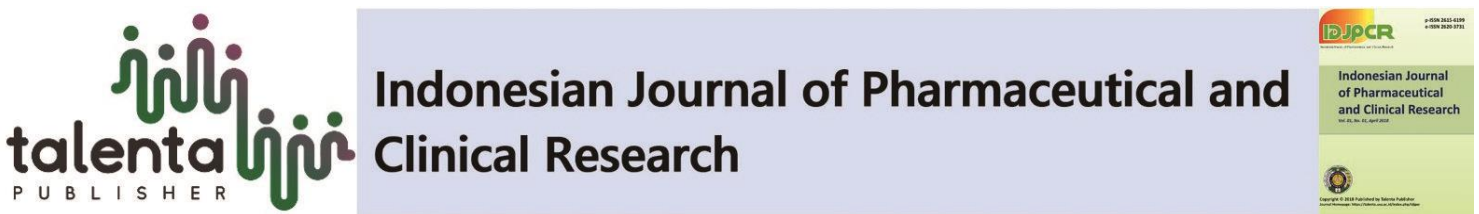

\section{Appropriateness of Antibiotic Utilization in Hospitalized Post-Surgery Patients}

\author{
Azizah Nasution ${ }^{1}$, Noor Fashilah ${ }^{1}$, and Sony Eka Nugraha \\ ${ }^{I}$ Department of Pharmacology, Faculty of Pharmacy, Universitas Sumatera Utara, Medan \\ 20155, Indonesia \\ ${ }^{2}$ Department of Pharmaceutical Biology, Faculty of Pharmacy, Universitas Sumatera Utara, \\ Medan 20155, Indonesia
}

\begin{abstract}
One of the most common health problems related to surgery is infection which needs treatment with antibiotics. Inappropriate use of antibiotics results in many problems including microbial resistance, interference of the required clinical outcomes, increasing side effects of the provided antibiotics and health resources utilization, causing toxic effects to the body organs, and even death. This study aimed to evaluate the appropriateness of antibiotic utilization on post-surgery patients admitted to Haji Adam Malik (HAM) Hospital, Medan, Indonesia. This three-month prospective descriptive study was conducted to evaluate the appropriateness of antibiotic utilization based on Gyssens method categorized into appropriate and inappropriate (in terms of dose, interval, route, too long provision, too short provision, less effective, toxicity, price, and the spectrum), and trustable literatures on post-surgery patients assessed from their medical records $(\mathrm{n}=31)$ in HAM Hospital Medan. Most (54.8\%) of the patients were females. The study proved that $23(74.2 \%)$ of the patients received appropriate/rational antibiotic therapy and $8(25.8 \%)$ of them received inappropriate antibiotic therapy consisted of problems with: inappropriate dose, $13 \%$; too long duration, $3.2 \%$ ); too short duration, $29 \%$. More than a quarter of the patients received inappropriate dosages of antibiotics.
\end{abstract}

Keywords: Antibiotics, Gyssens method, Post-surgery patients

\begin{abstract}
Abstrak. Salah satu masalah kesehatan yang selalu berhubungan dengan operasi adalah infeksi yang memerlukan terapi antibiotika. Penggunaan antibiotika yang tidak rasional akan menimbulkan berbagai masalah, termasuk resistensi resistensi mikroba, gangguan terhadap outcome klinik yang diinginkan, interference, peningkatan efek samping antibiotika yang diberikan dan sumber kesehatan yang digunakan, efek toksik terhadap organ tubuh, dan bahkan kematian. Penelitian ini bertujuan untuk mengevaluasi kesesuaian penggunaan antibiotika pada pasien paska operasi di Rumah Sakit Haji Adam Malik (HAM), Medan, Indonesia. Penelitian prospective descriptive tiga bulan ini dilaksanakan untuk mengevaluasi kesesuaian penggunaan antibiotika berdasarkan metode Gyssens yang dikategorikan menjadi tepat dan tidak tepat (dalam hal dosis, interval, rute, pemberian terlalu lama, pemberian terlalu singkat, kurang effective, toksisitas, harga, dan the spectrum, dan literature yang dapat dipercaya terhadap pasien paska operasi yang diakses dari medical records $(n=31)$ di Rumah Sakit HAM Medan. Umumnya $(54,8 \%)$ dari pasien adalah perempuan. Penelitian ini membuktikan bahwa 23 (74,2\%) dari pasien menerima antibiotika yang rasional dan $8(25,8 \%)$ dari mereka menerima antibiotika yang
\end{abstract}

*Corresponding author at: Department of Pharmaceutical Biology, Faculty of Pharmacy, UniversitasSumatera Utara, PadangBulan, Medan 20155, Indonesia

E-mail address: azizah@usu.ac.id 
tidak sesuai yang terdiri dari: dosis tidak sesuai, 13\%; penggunaan terlalu lama, 3.2\%); penggunaan terlalu singkat, 29\%. Lebih dari seperempat dari pasien menerima dosis antibiotika yang tidak rasional.

Kata kunci: Antibiotika, Gyssens method, Pasien paska operasi

Received 16 March 2019 | Revised 27 April 2019 | Accepted 25 May 2019.

\section{Introduction}

Surgical care has been an essential component of health care in many countries. With the increasing incidence of cancer, cardiovascular disease and traumatic injuries, then the effect of surgery on the public health care system also increases. Each year more than a hundred million of people get surgery due to many medical reasons [1].

In developed countries it was noted that surgery-related complications occurred were experienced by $3-16 \%$ of the patients. Meanwhile, in developing countries, the death rate associated with surgery was $5-10 \%$. In addition, infection and post-surgery complications are also serious issues in many countries [2]. In 2002, the Centers for Disease Control (CDC) and Prevention estimated that the incidences of nosocomial infections in hospitals were experienced by 1.7 million people and approximately 99,000 people died from these infections [3]. In Indonesia, nosocomial infection rates keep increasing. A survey conducted Indonesian Indonesian Hospitals proved that acquired nosocomial infection rate was varied between 2 to $18 \%$ due to surgical site infection [4].

Surgical site infection is one of the most common health problems related to post surgery. According to Noer, in developing countries, one of the diseases with high prevalence is infection that requires antibiotics treatment. Nevertheless, irrational use of antibiotics results in many problems including antimicrobial resistance, interference of the required clinical outcomes, increasing side effects of the provided antibiotics and health resources utilization, causing toxic effects to the body organs, and even death. These conditions will increase morbidity and mortality which ultimately lowering the the patients' quality of life [5]. The use of an antibiotic is said to be rational if it achieves maximum therapeutic effect while avoids the toxic effects, and minimizes its side effects as well as the development of antibiotic resistance [6].

Several studies on appropriateness of antibiotic use have been done in many hospitals in different parts of Indonesia. A study undertaken by a team in Dr. Soetomo Surabaya hospital and Dr. Kariadi Semarang hospital in 2002 showed that $83 \%$ of patients received antibiotics of which $60 \%$ were provided irrationally and in the department of Surgery, the rational antibiotic usage was only less than 20\%[7]. Likewise, a study conducted by Vindi Dertarani in the Department of Surgery, Dr. Kariadi Hospital period August to December 2008 confirmed that 
only $35.5 \%$ of the patients received rational use of antibiotics. The study proved that $52.3 \%$ of the patients received irrational use of antibiotics category $\mathrm{V}$ included into drug without indication [8]. Studies on appropriateness of antibiotic use are crucial to optimize the management of problems related to surgery and control of bacterial resistance to antibiotics.

Based on these facts, this study aimed to evaluate the appropriateness of antibiotic utilization on post-surgery patients admitted to HAM Hospital, Medan period June 2016-August 2016.

\section{Methods}

This prospective descriptive study was conducted to evaluate the appropriateness of antibiotic utilization using Gyssens method categorized into appropriate and inappropriate (in terms of dose, interval, route, too long provision, too short provision, less effective, toxicity, price, and the spectrum) [9] on post-surgery patients $(n=31)$ on three month-period of admission in HAM Hospital, Medan, Indonesia.

The samples included into this study were the medical records of post-surgery patients received antibiotics treatments. Ethical clearance of this study was obtained from the Health Research Ethical Committee of North Sumatera, School of Medicine, University of Sumatera Utara, Medan, Indonesia. The required data was prospectively extracted from three-month medical records and the status of post-surgery patients hospitalized in HAM Hospital. Characteristics of the patients and the provided antibiotics were classified, and descriptively analyzed [10]. Rationality of the antibiotics provided to each of the post-surgery patients was analyzed using Gyssens method that consists of appropriate (category 0), inappropriate in dose, interval, and route (category II), too long provision and too short provision (category III), less effective, toxicity, price, and the spectrum (category IV), unjustified therapy (category V), and insufficient records to categorize (category VI). All analyses were performed using the program of Statistical Package for the Social Sciences version 19.

\section{Results and Discussion}

During the study period, there were 75 post-surgery patients received antibiotics of which only 31 patients met the inclusion criteria.

\subsection{Characteristics of the Post-SurgeryPatients}

The characteristics of the post-surgery patients $(n=31)$ who received antibiotic regimens are shown in Table 1. As listed in Table1, most (54.84\%) of the post-surgery patients were female. Most (41.94\%) of them were in the age range of $46-55$ years. During the study period, the 3 age groups of the post-surgery patients with highest rates in decreasing order were the age range of 46-55 years followed by the age ranges of 26-35 and 36-45 years. 
Table 1. Characteristics of the Post-Surgery Patients $(n=31)$

\begin{tabular}{lcc}
\hline & Number & $(\%)$ \\
\hline Gender: & & \\
Males & 14 & 45.16 \\
Females & 17 & 54.84 \\
Age group (years): & & \\
$16-25$ & 2 & 6.45 \\
$26-35$ & 5 & 16.13 \\
$36-45$ & 5 & 16.13 \\
$46-55$ & 13 & 41.94 \\
$56-65$ & 4 & 12.90 \\
$>65$ & 2 & 6.45 \\
\hline
\end{tabular}

The Utilization of antibiotics in post-surgery patients is shown in Table 2 Overall, 44 antibiotic regimens consisted of 5 classes and 8 antibiotics were received by these patients.

Tabel 2. The Utilization of Antibiotics in Post-Surgery Patients $(n=31)$

\begin{tabular}{llcl}
\hline \multicolumn{1}{c}{ Class of antibiotics } & \multicolumn{1}{c}{ Antibiotics } & Number & $(\%)$ \\
\hline Cephalosporin & Ceftriaxone & 26 & 59.1 \\
& Cefadroxil & 4 & 9.09 \\
& Ceftazidime & 4 & 9.09 \\
& Cefepime & 1 & 2.27 \\
Carbamapenem & Meropenem & 3 & 6.82 \\
Nitroimidazole & Metronidazole & 3 & 6.82 \\
Aminoglycoside & Amikacin & 2 & 4.54 \\
Fluoroquinolone & Ciprofloxacin & 1 & 2.27 \\
\hline
\end{tabular}

The most widely used antibiotic was ceftriaxone which reached $59.1 \%$ of the overall regimens. Ceftriaxone is included into the third generation of cephalosporin with a broad spectrum antibacterial activity and effective for the treatment of infections caused by various gram positive and gram negative bacteria.

\subsection{Distribution of Antibiotics Provided to the patients $(n=31)$}

Antibiotics provided to the patients based on the type of antimicrobial therapy are shown in Table 3

Tabel 3. Type of The Antimicrobial Therapy Provided

\begin{tabular}{lc}
\hline \multicolumn{1}{c}{ Type of Therapy } & $(\%)$ \\
\hline Antimicrobial Drug Extended Empiric therapy & 54.55 \\
Antimicrobial Drug Documented therapy & 27.27 \\
Antimicrobial Drug Empiric therapy & 13.63 \\
Antimicrobial Drug Prophylaxis & 4.55 \\
\hline
\end{tabular}

Based on the type of therapy, it was proved that most (54.55\%) of the post-surgery patients were provided antimicrobial drug extended empirical therapy (ADET). This type of therapy was continued beyond 72 hours in the presence of negative culture result or in the absence of culture. The next second highest type of therapy was antimicrobial drug documented therapy 
(ADD) based on known cultured pathogen received by $27.27 \%$ of the patients. As listed in Table 3, there were only $13.63 \%$ of the patients received antimicrobial drug empirical therapies (ADE). This therapy was provided before culture results became available. Additionally, only $4.55 \%$ of the patients were prescribed antimicrobial drug prophylaxis (ADP).

\subsection{Appropriateness of Antibiotics Usage}

Gyssens method is an instrument widely used to evaluate the appropriateness of antibiotics usage in treatment of patients in various countries. In this study, only 4 of the 6 categories of Gyssens were detected in the treatment of the post-surgery patients. These categories were appropriate use of antibiotics, inappropriate dosing, too long treatment duration, and too short treatment duration. Result of the analysis of appropriateness of antibiotics provided to the postsurgery patients is listed in Table 4.

Table 4. Appropriateness of Antibiotics Provided to Post-Surgery Patients ( $n=31$ ) by Gyssens Method

\begin{tabular}{llcc}
\hline Category & \multicolumn{1}{c}{ Gyssens criteria } & $\begin{array}{c}\text { Number of } \\
\text { patients }\end{array}$ & Percentage (\%) \\
\hline 0 & Appropriate use & 17 & 54.8 \\
IIA & Inappropriate dosing & 4 & 13 \\
IIIA & Too long treatment duration & 1 & 3.2 \\
IIIB & Too short treatment duration & 9 & 29 \\
\hline
\end{tabular}

As demonstrated in Table 4, most (54.8\%) of the patients were provided appropriate or rational use of antibiotics (category 0), while the rest (45.2\%) of them received irrational use of antibiotics.

The greatest inappropriate use of antibiotics obtained was the used of antibiotics with too short duration (category IIIB) that reached up to $29 \%$ followed by $13 \%$ of inappropriate dosing (category IIA) and 3.2\% the antibiotics use with too long duration (Category IIIA).

Several similar studies with a wide range of appropriateness use of antibiotics have been undertaken elsewhere. In 2008, a study conducted by Vindi Dertarani in the Department of Surgery in Dr Kariadi Hospital Indonesia obtained the rational antibiotics use was only 35.5\% of the patients involved in the treatment [8]. Other study undertaken by Rossefine in HAM Hospital Medan Indonesia in 2012 argued that the rational use of antibiotics were provided to nearly half $(47.5 \%)$ of the patients [11]. This difference was thought to occur due to many complicated factors including the wide spectrum of the bacterial resistance to antibiotics and patient variability. The rational use of antibiotics can be achieved if all healthcare providers including physicians, pharmacists, nurses, and other healthcare providers work together as a team. Additionally, physicians should prescribe antibiotics based clinical practice guidelines, clinical conditions of the patients, and bacterial resistance [12]. 
The use of antibiotics is considered rational if it is provided to patients with accurate diagnosis. If the diagnosis was not correctly established, inappropriate selection of drugs tend to occur. As a result, many medical problems can be experienced by that patient [12].

\subsection{Inappropriate of Antibiotic dose (Category IIA)}

Inappropriate of antibiotic doses experienced by $13 \%$ of the patients are described in Table 5. Based on Table 5, there were 3 post-surgery patients given antibiotics with too high doses. Excessive dose, especially for a drug with a narrow therapeutic range tend to have high risk of adverse events. Contrarily, too low dose will not guarantee the achievement of the expected therapeutic levels $[13,14]$.

Tabel 5. Incidence of Inappropriate Use of Antibiotics Included into Category IIA)

\begin{tabular}{|c|c|c|c|c|}
\hline Antibiotics & $\begin{array}{c}\text { Number of } \\
\text { patient }\end{array}$ & Dose provided & Recommended Dose & $\begin{array}{c}\text { Dose } \\
\text { problems }\end{array}$ \\
\hline \multirow{2}{*}{$\begin{array}{l}\text { Ceftriaxone inj } \\
\text { Amikacin inj }\end{array}$} & 1 & $3 \mathrm{~g} / 12 \mathrm{hr}$ & $1-2 \mathrm{~g} / 24 \mathrm{hr}$ & Too high \\
\hline & 1 & $1 \mathrm{~g} / 12 \mathrm{hr}$ & $15-22.5 \mathrm{mg} / \mathrm{kgBW} /$ day & Too high \\
\hline Metronidazole inj & 1 & $500 \mathrm{mg} / 8 \mathrm{hr}$ & $\begin{array}{l}7.5 \mathrm{mg} / \mathrm{kgBW} \text { every } 6 \\
\mathrm{hr}\end{array}$ & Too high \\
\hline
\end{tabular}

\subsection{Inappropriate duration of Antibiotics use}

Inappropriate use of antibiotics by duration categorized into too long provision (Category IIIA) and too short provision (Category IIIB) is shown in Table 6. Recommended doses of these antibiotics are also demonstrated in Table 6 [15]. Based on Table 6, it was identified that one patient was provided ceftriaxone too long (25days). Long term provision of ceftriaxone can result in many consequencies, including thrombocytosis, leucopenia, eosinophilia, elevated blood urea nitrogen, and negative injection site reactions (swelling, pain, and hard lump), serious microbiota dysbiosis which disrubts the immune system as well as bacterial resistance $[16,17]$. 
Table 6. Inappropriate Use of Antibiotics by Treatment Duration

\begin{tabular}{|c|c|c|c|c|}
\hline $\begin{array}{l}\text { Antibiotics } \\
\text { provided }\end{array}$ & $\begin{array}{l}\text { Number } \\
\text { of } \\
\text { patient }\end{array}$ & $\begin{array}{c}\text { Dose } \\
\text { provided }\end{array}$ & $\begin{array}{l}\text { Recommended } \\
\text { Dose }\end{array}$ & $\begin{array}{c}\text { Treatment } \\
\text { Duration }\end{array}$ \\
\hline $\begin{array}{l}\text { Ceftriaxone } \\
\text { inj }\end{array}$ & 1 & $\begin{array}{l}1 \mathrm{~g} / 12 \text { hours } \\
\text { for } 25 \text { days }\end{array}$ & $1 \mathrm{~g} / 12$ hours for $4-14$ days & Too long \\
\hline $\begin{array}{l}\text { Ceftazidime } \\
\text { inj }\end{array}$ & 1 & $\begin{array}{l}1 \mathrm{~g} / 8 \text { hours for } \\
\text { three days }\end{array}$ & $1 \mathrm{~g} / 8$ hours for 14 days & Too short \\
\hline $\begin{array}{l}\text { Metronidazole } \\
\text { inj }\end{array}$ & 1 & $\begin{array}{l}500 \mathrm{mg} / 8 \text { hours } \\
\text { for } 5 \text { days }\end{array}$ & $500 \mathrm{mg} / 8$ hours for $7-10$ days & Too short \\
\hline \multirow{2}{*}{ Cefadroxil } & 1 & $\begin{array}{l}500 \mathrm{mg} / 12 \text { hour } \\
\text { for } 2 \text { days }\end{array}$ & \multirow[t]{2}{*}{$500 \mathrm{mg} / 12$ hours for 10 days } & \multirow[t]{2}{*}{ Too short } \\
\hline & 1 & $\begin{array}{l}500 \mathrm{mg} / 12 \text { hours } \\
\text { for } 4 \text { days }\end{array}$ & & \\
\hline \multirow{2}{*}{ Ceftriaxoneinj } & 2 & $\begin{array}{l}1 \mathrm{~g} / 12 \text { hours for } \\
2 \text { days }\end{array}$ & \multirow[t]{2}{*}{$1 \mathrm{~g} / 12$ hours for $4-14$ days } & \multirow{2}{*}{ Too short } \\
\hline & 3 & $\begin{array}{l}1 \mathrm{~g} / 12 \text { hours for } \\
3 \text { days }\end{array}$ & & \\
\hline
\end{tabular}

Based on Table 6, nine after-surgery patients received antibiotics with too short duration not complied with the appropriate use of antibiotics recommended. Too short or too long administration of drugs not only would significantly affect the outcome of treatment but also contribute to the emerging resistance of phatogen globally [13].

\section{Conclusions}

The present study summarized that the most widely provided antibiotics in the post-surgery patients hospitalized in HAM Hospital during the three-month period was cephalosporin antibiotics amounted to $79.55 \%$ in which the most widely used antibiotic was ceftriaxone $(59.1 \%)$. Most $(54.8 \%)$ of the post-surgery patients received rational use of antibiotics. However, $45.2 \%$ of them were provided inappropriate use of antibiotics. The results of this study should be highlighted by the healthcare providers to avoid many negative clinical impacts and minimize the continuous bacterial resistance.

\section{REFERENCES}

[1] World Health Organization, "WHO Guidelines for Safe Surgery: Safe Surgery Saves Lives" 2016 . Available: www.npsa.nhs.uk/advice [Assessed: September 20 ${ }^{\text {th }} 2017$ ]

[2] World Health Organization, World guidelines for safe surgery first edition 2008. Available: $\quad$ http://www.who.int/patientsafety/safesurgery/toolsresources/9789241598552/en/ [Assessed: January 21 ${ }^{\text {st }}$, 2017]

[3] B. Mauger, A. Marbella, E. Pines, R. Chopra, E. R. Black, and N. Aronson, "Implementing quality improvement strategies to reduce healthcare-associated infections: 
A systematic review," American Journal of Infection Control, vol. 42, no. 10, pp. S274S283, Oct. 2014.

[4] Jeyamohan D. Prevalence of Nosocomial Infection in Post-Operative Patients in Department of Surgery Haji Adam Malik Hospital Medan Period April to September 2010. Available from: http://repository.usu.ac.id/handle/123456789/21521. Assessed on $13^{\text {th }}$ June 2019.

[5] R. Ofori-Asenso, P. Brhlikova, and A. M. Pollock, "Prescribing indicators at primary health care centers within the WHO African region: a systematic analysis (1995-2015)," BMC Public Health, vol. 16, no. 1, Aug. 2016.

[6] World Health Organization, "WHO Global Strategy for Containment of Antimicrobial Resistence 2001". page: 1-55.

[7] The AMRIN Study Group. (2005). Antimicrobial resistence, antibiotic usage and infection control; a self-assesment program for Indonesian hospital. Directorate General of Medical Care.

[8] Dertarani, V. (2009). Evaluation of Antibiotics Usage Based on Gyssens Method in PostOperative Patients in Department of Surgery, Dr. Kariadi Hospital Period August to December 2008. Faculty of Medicine.

[9] J. W. M. van der Meer and I. C. Gyssens, "Quality of antimicrobial drug prescription in hospital," Clinical Microbiology and Infection, vol. 7, pp. 12-15, Dec. 2001.

[10] World Health Organization, "World Health Organization. Regional Office for the Western Pacific. Health research methodology: a guide for training in research methods", World Health Organization; 2001.

[11] Rossefine EF, Qualitative evaluation of Antibiotics Use in Post-surgery Patients Admitted to Haji Adam Malik Hospital applying Gyssens Method Period July to September 2012.Medan: Universitas Sumatera Utara

[12] World Health Organization, "Rational use of medicines, Fact sheet N³38 May 2010", Available : http://www.who.int/mediacentre/factsheets/ fs338/en [ accessed: October $22^{\text {nd }}$ 2017]

[13] R. I. Aminov, "A Brief History of the Antibiotic Era: Lessons Learned and Challenges for the Future," Frontiers in Microbiology, vol. 1, 2010.

[14] S. B. Zaman, M. A. Hussain, R. Nye, V. Mehta, K. T. Mamun, and N. Hossain, "A Review on Antibiotic Resistance: Alarm Bells are Ringing," Cureus, Jun. 2017.

[15] Drugs.com. Prescription drug information, interactions, and side effects. Available: http://www.drugs.com, [Accessed:June 26 ${ }^{\text {th }}$ 2019]

[16] E. Leung, D. E. Weil, M. Raviglione, and H. Nakatani, "The WHO policy package to combat antimicrobial resistance," Bulletin of the World Health Organization, vol. 89, no. 5, pp. 390-392, May 2011.

[17] Y. Guo, X. Yang, Y. Qi, S. Wen, Y. Liu, S. Tang, R. Huang, and L. Tang, "Long-term use of ceftriaxone sodium induced changes in gut microbiota and immune system," Scientific Reports, vol. 7, no. 1, Feb. 2017. 